\title{
Evaluation of Credit Procedure at Cooperative Employee Angkasa Pura Juanda Airport Surabaya to Suppress The Loss of Bad Credit
}

\author{
Fanita Artisari \\ Faculty of Economics and Business Airlangga University Surabaya, Indonesia \\ Email: fanita@mail.com
}

\begin{abstract}
Bad debts that occurred in KSP Kokapura the lowest in April 2016 and the highest in December 2016. The unstable level of bad loans in KSP Kokapura Juanda Surabaya even at the end of the year experienced the highest rate of bad debts, a reason researchers to know more about the procedure of granting credits applied to the cooperative. Type of approach used in this research is descriptive qualitative approach, meaning this research intends to understand the phenomenon experienced by the subject of research. Credit conditions KSP Kokapura in 2016 described shows a tendency to decrease the quality of analysis, supervision and control of cooperatives against prospective creditors and / or active creditors. This is indicated by the percentage of delinquent rates this year which increases, running from $1.34 \%$ to $3.61 \%$ with an average of $2.23 \%$. With the flowchart crediting process to members of KSP Kokapura, is expected to overcome the problem of bad loans that occurred in this cooperative. The procedure of crediting implementation at the Cooperative Employee Angkasa Pura Juanda Airport Surabaya is an easy and simple procedure for members or prospective members. How to solve there is bad credit in the process of the process that is by giving a compulsory penalty pens in ENT warranty; Jamsostek; Pension fund; Other Income to be received from the Company.
\end{abstract}

Keywords: Evaluation of Credit, Bad Credit, Procedure of granting credit, Non Performing Loan (NPL).

\section{Introduction}

With the current economic development, capital providers are needed in this case, one form of business is a fund provider cooperatives. So the purpose of the cooperative itself is to improve the standard of living and welfare of its members and meet the needs of its members. Development in the cooperative business is strongly influenced by the number of debtors owned. Similarly, the level of cooperative profits, the more debtors then the level of profit on the cooperative automatically increased and if the debtor is reduced then the profits derived decreased.

Granting credit is a form of business undertaken by cooperatives to process capital owned from the donation of members' savings to lend to members by taking advantage of interest payments from members who make loans. Where according to Kasmir (2009: 102) the definition of credit is the provision of money or bills that can be equalized, based on a loan agreement or agreement between the bank with another party that requires the borrower to repay the debt after a certain period of time with the giving of interest. This should be considered by the cooperative in which in providing loans or credit cooperatives should pay attention to the convincing factors in lending to ensure smooth credit payments. This is done to prevent the occurrence of bad debts that can disrupt the business of cooperatives and also harm the cooperative, especially in the achievement of profit.

Broadly speaking, by looking at the opportunities and economic needs today, Koperasi Simpan Pinjam (KSP) is cheaper and easier compared to other credit institutions such as banking. Judging from the ease in 
crediting requirements, members will be easier to transact with KSP because to apply and selection on credit applications easier than other credit agencies. Usually in KSP, unsecured members can get credit but for non members can only use BPKB. The level of ease in getting a loan becomes an opportunity for the development of Savings and Loans in a Cooperative.

KSP Employee Cooperative Angkasa Pura (Kokapura) is one of the cooperatives in Surabaya which is engaged in lending. Similar to other KSPs, KSP Kokapura provides loans in the form of credit money to members in need and cooperate with other parties. Judging from the development of its members, KSP Kokapura experienced an increase in the number of members from year to year.

The success of lending is inseparable from the lending procedures undertaken in the management of lending to members. The crediting procedure is a provision that guarantees the lender's right to lend to the borrower in order for the loan to be returned accordingly in other words that the lending procedure requires the borrower to repay the loan in accordance with the agreement with the borrower and the specified interest. In lending activities, the constraints typically encountered in lending are bad debts and there may be other constraints. Similarly in KSP Kokapura, according to the initial survey of interviews with Secretary KSP Kokapura there is also a problem that is the existence of bad debts that continue to occur from year to year.

Bad debts that occurred in KSP Kokapura the lowest in April 2016 and the highest in December 2016. The unstable level of bad loans in KSP Kokapura Juanda Surabaya even at the end of the year experienced the highest rate of bad debts, a reason researchers to know more about the procedure of granting credits applied to the cooperative.

\section{Details Experimental}

\subsection{Materials and Procedures}

Type of approach used in this research is descriptive qualitative approach, meaning this research intends to understand the phenomenon experienced by the subject of research. The phenomenon is described in the form of language or words. Determination of location in this research that is using purposive area method that is choosing location determined intentionally in accordance with research purpose. This research was conducted at Savings and Loans Cooperative Employee Cooperative Angkasa Pura (KSP Kokapura) Surabaya based in Juanda Surabaya. While the time of study conducted during April 2017 to June 2017.

The data obtained are data about credit granting procedures in Savings and Loans Cooperative Cooperative Employee Angkasa Pura (KSP Kokapura) Surabaya. Secondary data in this research are documentation of cooperative history, organizational structure, credit development report of KSP Kokapura and documentation of problem loans in 3 periods.

\section{Results and Discussion}

\subsection{Procedure of Credit on Cooperative Employee Angkasa Pura Juanda Airport Surabaya}

The procedure of granting credit to the Cooperative Employee Angkasa Pura Juanda Airport Surabaya is quite simple, with easy requirements, and a fast process. This can facilitate prospective borrowers, so many members are interested to apply for credit to the Cooperative. The procedure or flow that has been set by the Employee Cooperative Angkasa Pura Juanda Airport Surabaya as follows: 


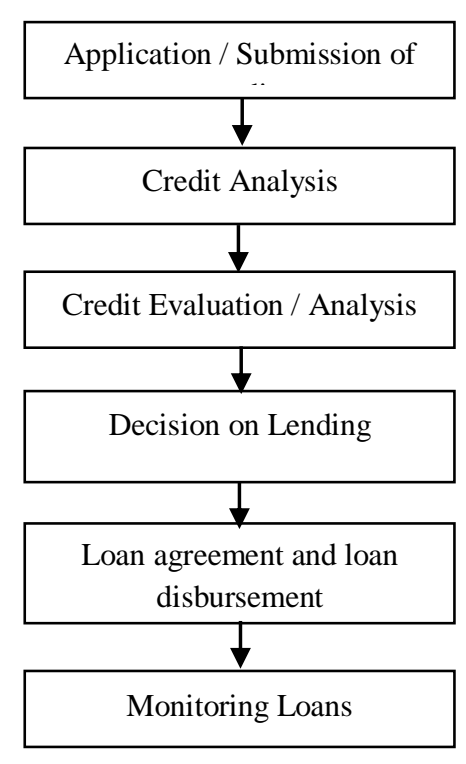

Figure 1 Implementation Procedures of Credits Cooperative Employee Angkasa Pura Juanda Airport Surabaya

\subsection{Troubled Credit}

If seen from the average number of credit users in 2016 that fell by $29 \%$ is likely due to the increase in profit obtained by PT Angkasa Pura in 2016 which reached 6.65 trillion. It is possible for employees to get more incentives from the achievement of the profits, so that creditors on KSP Kokapura have decreased this year. The analysis by the author seen from the realization of loans in the current year for active credit and the problematic are as follows.

Throughout 2014, the level of arrears that occurred in KSP Kokapura in each month runs about $0.98 \%$ to $2.66 \%$, with an average of $1.58 \%$. This figure is much smaller than the maximum standard set by Bank Indonesia, in other words KSP Kokapura in good health. The movement of delinquency rates in 2015 runs at $0.92 \%$ to $1.85 \%$ with an average of $1.44 \%$. This figure is smaller than the condition ratio in 2014 , which has an average of $1.58 \%$. This indicates that KSP has made progress in analyzing, supervising and controlling the credit given to customers.

Credit conditions KSP Kokapura in 2016 described shows a tendency to decrease the quality of analysis, supervision and control of cooperatives against prospective creditors and / or active creditors. This is indicated by the percentage of delinquent rates this year which increases, running from $1.34 \%$ to $3.61 \%$ with an average of $2.23 \%$.

From the results of interviews with managers, it is known that the occurrence of bad loans in Cooperative Employee Angkasa Pura Juanda Airport Surabaya caused by:

1. Internal parties of cooperatives who make mistakes in the analysis or lack of supervision;

2. The customer as a borrower who is suddenly transferred or retired; and

3. External circumstances that include changes in economic conditions due to the disaster. follows:

Curative measures undertaken by KSP Kokapura in addressing the problem of non-performing loans are as

1. Contact the borrower,

2. Provide a warning letter to the borrower,

3. Confiscation of guarantee goods,

4. Sale of warranty items to repay its debts, or 
5. Rescheduling by making changes to credit terms concerning payment schedules, penalties imposed on the borrower's negligence, as well as changes in the amount of credit installment as stated in the loan agreement

Associated with the problem of bad debts that occurred, the authors proposed alternative solutions at the Cooperative Employee Angkasa Pura Juanda Airport Surabaya in the process of granting credit to members who are depicted in the flowchart below.

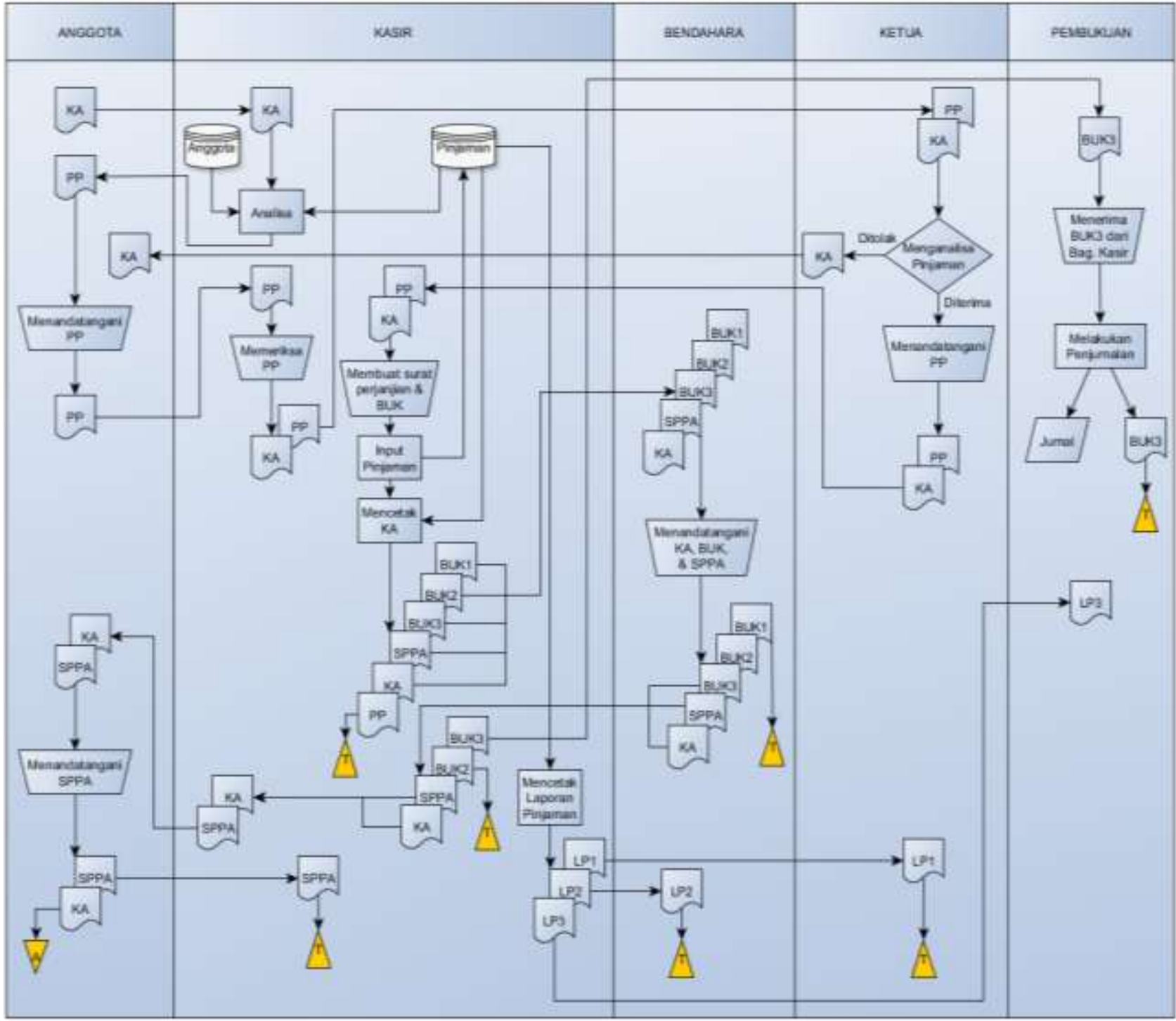

Fig. 2 Flowchart Proposed Granting of Credit to Cooperative Employee Angkasa Pura Juanda Airport Surabaya

\section{Proposed Loan Procedure:}

1. Members bring a member book to the cooperative and submit it to the cashier for loan application.

2. The cashier checks the member's book by checking the membership and loan on the computer.

3. If not qualified then the submission is rejected and the member book is returned, if accepted then the member is given a loan application letter.

4. Members fill in the loan application letter (PP) and return to the cashier.

2. The cashier gives loan application letter and member book to the board. 
3. The board member analyzes the loan application if the loan application letter is received and if it is rejected the member book is returned.

4. If accepted the cashier make a loan agreement member (SPPA) and make a slip of money out (BK) 3 duplicate and input the loan on the computer and print it on the book members.

5. Cashier submits member loan agreement (SPPA), member book and money out slip (BK) to sign the treasurer. Then the member loan agreement (SPPA), member book, money out slip 2 (BK2) and money out slip 3 (BSU3) are returned to the cashier while the outgoing money slip (BK1) is filed by the treasurer as proof of money out.

6. After signing by member book cashier and member loan agreement letter (SPPA) is returned to member and ask member to sign SPPA.

7. Members sign SPPA and return to the cashier.

8. The cashier archives SPPA in SPP and BK 2 archives in archives in BK archive. While BK 3 is given to bookkeeping.

With the flowchart crediting process to members of KSP Kokapura, is expected to overcome the problem of bad loans that occurred in this cooperative.

\section{Conclusions}

Based on the results and discussion can be concluded that:

1. Implementation procedure of credit extension on Cooperative Employee Angkasa Pura Juanda Airport Surabaya starting from credit proposal, credit analysis, credit evaluation, giving of credit decision, document preparation, credit disbursement, document archiving and repayment of loan is easy and simple procedure for members or prospective members.

2. How to settle if there is bad credit in the implementation of credit process on Cooperative Employee Angkasa Pura Juanda Airport Surabaya is by giving a fine.

3. To guarantee the order of debt repayment under the Loan Agreement whether arising from principal, interest, penalties and other costs, the borrower shall be obliged to submit a guarantee including ENT; Jamsostek; Pension fund; Other Income to be received from the Company.

\section{References}

[1]. Ardiyos, 2004, Kamus Besar Akuntansi, Bandung: Alfabetis.

[2]. Hasibuan S.P., 2007, Dasar-dasar Perbankan, Jakarta: PT. Raja Grafindo Persada.

[3]. Hatsari, Fitri Khaula, dkk, 2014. Evaluasi Sistem dan Prosedur Penyaluran Kredit Konsumtif dalam Upaya Mendukung Pengendalian Intern pada Koperasi (Studi Kasus pada Koperasi Karyawan PRIMKOPPOS Kota Malang), Jurnal Administrasi Bisnis (JAB), Vol. 11, No 1, Hal: 1-10.

[4]. Indriantoro, N. dan Supomo, B., 2011, Metodologi Penelitian Bisnis untuk Akuntansi Dan Manajemen, Edisi Pertama, Yogyakarta: BPFE.

[5]. Kasmir, 2009. Bank dan Lembaga Keuangan Lainnya, Rajawali Pers, Jakarta.

[6]. Kasmir, 2010. Dasar-Dasar Perbankan, Rajawali Pers, Jakarta.

[7]. Pasolang, Ronald, 2010, Evaluasi Sistem pemberian Kredit (Studi Kasus pada PT BPR Hidup Arthagraha, Muntilan, Skripsi, Universitas Sanatha Dharma, Yogyakarta.

[8]. Peraturan Bank Indonesia Nomor 15/2/Pbi/2013 tentang Penetapan Status dan Tindak Lanjut Pengawasan Bank Umum Konvensional. 
[9]. Peraturan Menteri Negara Koperasi, dan Usaha Kecil dan Menengah Republik Indonesia Nomor: 19/Per/M.Kukm/Xi/2008 Tentang Pedoman Pelaksanaan Kegiatan Usaha Simpan Pinjam oleh Koperasi.

[10]. Rivai, V., 2006, Manajamen Sumber Daya Manusia untuk Perusahaan, Jakarta: PT. Raja Grafindo Persada.

[11]. Rudianto, 2008, Pengantar Akuntansi, Erlangga: Jakarta.

[12]. Soemarso, 2005, Akuntansi Suatu Pengantar, Edisi Revisi, Jakarta: Salemba Empat.

[13]. Supriyono, M., 2011, Buku Pintar Perbankan, Yogyakarta: Penerbit Andi.

[14]. Surat Edaran Bank Indonesia No.31/1/UPPB, 12 November 1998 Tentang Kualitas Kredit.

[15]. Undang-Undang Republik Indonesia Nomor 10 Tahun 1998 (10/1998) Tentang Perubahan Atas Undang Undang Nomor 7 Tahun 1992 Tentang Perbankan.

[16]. Undang-Undang Republik Indonesia Nomor 14 Tahun 1967 Tentang Pokok-Pokok Perbankan.

[17]. Wenie, Darminto, Husaini, 2015, Evaluasi Sistem dan Prosedur Pemberian Kredit Modal Kerja dalam Upaya Mengatasi Kredit Bermasalah (Studi kasus pada PD BPR Tugu Artha Malang Periode Tahun 2009-2011), Jurnal Administrasi Bisnis (JAB), Vol. 22, No. 2, Hal:1-7.

[18]. Widiyanti, N., 2005, Dinamika Koperasi, Jakarta: Rineka Cipta. 